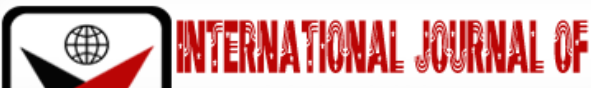

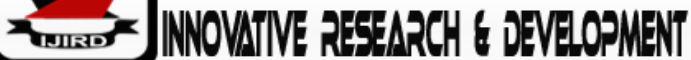

ISSN 2278-0211 (Online)

\section{Students in Off-Campus Accommodation in the University of Education, Winneba and the Effect on Academic Activities, Ghana}

\author{
Catherine Sih Njia \\ Tutor, Department of Home Economics, Komenda College of Education, Ghana \\ Christian Darabor \\ Tutor, Department of Education, Komenda College of Education, Ghana
}

\begin{abstract}
:
The provision of accessible, decent, safe and academically conducive accommodation for students in higher institutions is of great importance to enable the students perform academic activities excellently. In Ghana, regardless of Government's efforts to meet the accommodation needs of all tertiary students; there is still the issue of accommodation deficit among students in various campuses. This phenomenon has called for accommodation policies in various universities in Ghana, including University of Education, Winneba. This paper investigates students in offcampus accommodation in relations to factors influencing choice of accommodation and effect of off-campus accommodation on students' academic activities in University of Education, Winneba. Descriptive survey was employed for the study. Using multistage sampling (stratified, purposive, convenience and random sampling), 250 respondents were selected for the questionnaire survey. Frequencies, percentages and mean values organized in tables were statistical tools for analysis. The study revealed that majority of students on off-campus accommodation in UEW take into account factors such as security, utility, sanitation, condition of apartment and proximity, including number of occupants, neighbourhood and cost of the apartment when choosing accommodation. Subsequently, the study shows that off-campus accommodation has no adverse effect on academic activities on majority of students' in UEW regarding opportunity to do private studies; lateness to lecture; lateness in submission of assignment; poor performance in examination and quizzes. This notwithstanding, off-campus accommodation in UEW adversely affect students' group work; access to library and access to internet. The study recommends that providers of hotels, flats and compound homes that accommodate of-campus students should continue to ensure the provision of adequate security, toilets and other domestic facilities as well as keeping the sanitation clean to attract more students. However, the facility providers should provide internet at their premises to enable students in off-campus accommodation get access to internet, since internet use is inevitable in doing academic work in recent times. Further, students in offcampus accommodation are encouraged to form study groups particularly those offering the same programmes and courses.
\end{abstract}

Keywords: Off-campus accommodation and performance of academic activities

\section{Introduction}

The provision of accessible, decent, safe and academically conducive accommodation for students in higher institutions is of great importance to enable the students perform academic activities excellently. According to Modebelu and Chinyere (2009), students' accommodation is the pivot around which all students' activities revolve. Accommodation is a fundamental need for students' success as espoused by Maslow (1943) in his hierarchy of needs theory where among other things food, clothing and shelter are classified as basic needs for human. Imperatively, favourable and functional accommodation is paramount to the improvement in the academic activities of students including those in public tertiary institutions.

In many countries all over the world, governments have been the main provider of students' accommodation for public higher institutions. For instance, in France, the Centre National des Oeuvres Universitaire set Scolaires (CNOUS, 2009) heads a network that manages student social services, from housing to food to managing student financial aid. Similarly, in the United States of America, the National Association of Housing Co-operatives (NAHC), works together with Canada through the North American Students Cooperation (NASCO) to facilitate and provide affordable housing through a network of local and regional cooperatives students (Osfield \& Terrell, 2009). Specifically in Ghana, there is as yet very little national policy and regulation in the field of student housing (Dako-Gyeke \& Oduro, 2013). However, it is common knowledge that Government of Ghana has been at the forefront of providing accommodation for tertiary institutions. A responsibility charged on Ghana Education Trust Fund (GETFund) (Ghana education trust fund, retrieved on 
10/06/2021http://www.getfund.gov.gh).In this study, students' accommodation is regarded as a room, group of rooms or building in which someone may live or stay. This may be otherwise referred to as hostel.

In the face of growing enrolment of students in tertiary education globally, students' accommodation has become one of the teething problems faced by higher institutions in developing country, where Ghana is no exception(Nimako \& Bondinuba, 2013).Consequently, due to inadequate resources and funding the government of Ghana enacted tertiary students' accommodation policy to allow for private participation in providing sufficient accommodation for tertiary students (Nimako and Bondinuba (2013). This called for various Universities in Ghana, including University of Education, Winneba to make policy on student's accommodation. Prominent of such tertiary students' accommodation is the one known as 'In-Out-Out-Out Student Housing Policy'. The 'In' implies on-campus accommodation for first year students. This means that first year's students are allocated rooms in the various halls of residents on the university campus. On the other hand, the 'Out-Out-Out indicates that continuing students look for their own accommodation outside campus mostly built by private individuals. This situation is what is described as off-campus accommodation.

There are growing concern of students, parents and other stakeholders regarding the conditions of some of the off-campus accommodation facilities. Such concerns include high cost of rooms, overcrowding, high cost of utility bills, availability and functionality of basic facilities such wash-rooms, toilet, kitchen and others. For instance, in $2017 / 2018$ academic year enrolment of UEW students was 18,957 out of which about $10 \%$ was accommodated on campus. This implies that the remaining $90 \%$ of students are accommodated off-campus. This study therefore seeks to assess the status of off-campus accommodation to UEW students in relations to availability and functionality of facilities and whether affects students' academic activities. The study considers off-campus accommodation as an educational input that affects the educational output of the students and thus the internal efficiency of the University.

The paper is presented in five sections including this section One Section 1on background to the study. Section 2 provides review of related literature from past studies on factors influencing students' choice of off-campus accommodation and effects of off-campus accommodation on students' academic activities as a way of putting the study into perspective. The methodology used for this research is presented in Section 3. Results, analysis and discussion of findings are presented in Section 4. Finally, conclusions recommendation and areas of future research are proposed in Section 5.

\section{Originality and Significance of the Study}

Although studies had shown varying trends on university students' accommodation issues in relations to academic performance all over the world and Ghana in particular, it has been agreed that tertiary students' accommodation and its related effects on academic are still observable. Notwithstanding, this paper presents the first ever study on Students in off-campus accommodation and its effect on academic activities in the university of education, Winneba. Results and recommendations will contribute to existing literature and can also be used in academic capacity to study the trend of student's off-campus accommodation in other tertiary institutions in Ghana and elsewhere. School authorities, teachers and students may review issues regarding accommodation in tertiary institutions in the word-over to inform accommodation policy.

\section{Factors Influencing Students' Choice of Off-Campus Accommodation}

Students are likely to consider several factors in choosing their off-campus accommodation. Among such factors is the condition of the apartment. Conditions of an apartment is associated with age of the building, size and shape the bedroom, walls, ceiling, carpet on floor, lighting fixtures, furniture, including toilet facility. When these facilities are available and functioning, the apartment is seen to be in good condition. On the other hand, the absence of these facilities in an apartment renders it in poor condition. In this regard, poor condition of apartment is associated with a wide range of health conditions, including respiratory infections, asthma, lead poisoning injuries, and mental health (Krieger \& Higgins, 2002). Houses without good facilities such as toilet, bath, kitchen and good wall condition are nothing but shelter (Cohen, 2003).This indicates that students are likely to choose apartments which are in good condition.

The implication as espoused by Korevaar (2010) is that the quality of the housing may sometime result in paying additional housing rental costs and students would pay without complaining. Relatively, Bromley (2006) argues that offcampus housing for students are frequently overpriced due to low supply, and are provided by landlords who do not keep up with maintenance and repairs. The effect is that high cost of accommodation may lead some students to leave with friends. Leaving with friends possibly may come with its attendant challenges on the students. Importantly, the cost of accommodation varies greatly depending on the location as well as the type of accommodation. In the context of offcampus accommodation, cost of accommodation is dependent on rental rates, distance from university facilities, room safety, room size, hostel security, and other facilities in the hostel (Khozaei, 2010). Location refers to the specific placement of a house. The argument is that location of accommodation is often associated with transportation costs, security of jobs, moving expenses, and more time for daily activities (de Araujo \& Murray, 2010). As soon as one settles in a location, one is subject to the externalities that neighbourhood effects impose (Bromley, 2006).

The term neighbourhood can be defined as the vicinity in which people live (Macmillan English Dictionary.com, 2012). Location and neighbourhood effect are likely to inform choice of accommodation attributes are perceived as the key factor when it comes to choosing accommodation (de Araujo \& Murray, 2010). In effect, students may prefer off-campus residences to on-campus residences due to lack of privacy, high noise level as well as having to share bed space that distinguish them from the rest of the settlement and it shape their lives. Some students choose privately owned residences considered to be affordable, decent and close to campus with adequate facilities and mostly offer privacy (Najib et al., 2011). A decent neighbourhood may create a feeling of satisfactorily conducive environment for learning (Khozaei, 2010). 
Another factor likely to inform students' choice of off-campus accommodation is Sanitation. Arguably, sanitation is the inventions to reduce people's exposure to diseases by providing a clean environment for them to live in and to ensure measures to break the cycle of disease. A good sanitation includes hygienic management of human and animal excreta, fuse and wastewater, control of disease vectors and the provision of washing facilities for personal and domestic hygiene (Macmillan Dictionary.com, 2012). More so, sanitation is the state of cleanliness of the place, community or people particularly relating to those aspects of human health including the quality of life determined by physical, biological, social and psychological factors in the environment. Therefore sanitation are measures put in place to ensure a hygienic environment (Mensah, Yeboah-Manu, Owusu-Darko, \& Ablordey, 2002). Again, adequate sanitation, together with good hygiene and safe water, are fundamental to good health, social and economic development(Mensah et al., 2002).

This implies that when students reside in areas where the sanitation is adequate, all things being equal, they would experience lower health system costs, fewer days lost at school through illness or through caring for an ill relative, and convenience time savings time not spent queuing at shared sanitation facilities or walking for open defecation (Mensah et al., 2002). Security as a factor influencing student's choice of accommodation implies a stable, relatively predictable environment in which individual or group may pursue its ends without harm or fear of disturbance (Rugg, Rhodes, \&Jones, 2000). Similarly, Brooks, (2010) defines security as crime prevention, security technology and risk management or loss prevention. Therefore, security can be said to be the measures put in place to free a person's mind from the fear of the unknown. This indicates that adequate security at students' place of residence is important because it would give a peaceful environment necessary for learning (Kenyon, 1997).

\section{Effect of Off Campus Accommodation on Students' Academic Activities}

Neema (2003) conducted a study on the impact of off-campus accommodation on student's performance at the University of Namibia campus. In the study, students' academic performance was measured by grade point average obtained from the university registrar as a primary source of students' academic performance. Student's perceptions of living and studying environments regarding adequacy of the library, campus safety, differences in perceptions between students living in old-style and new-style hostels were sought. The study revealed that off campus student's performance was lower than those on campus. In a similar study, Ndoma (2018) investigated the effects of shortage of accommodation on students' performance in the private tertiary institutions in Botswana.

The study also found out that lack of hostel accommodation encourages truancy and consequently poor concentration on academic work. This shows that off-campus accommodation leads to truancy and poor concentration on academic work by students. This finding agrees with Neema (2003) that students on off-campus accommodation perform lower than their on-campus counterparts. In a related study, Agus and Makhbul (2002) found among other things a positive relationship among students' performance as against demographic, active learning, students' attendance and students housing environment as well as family income. This indicates that a good housing environment is likely to promote students' academic activities regardless of whether on-campus or off-campus. Sifuna (2012) in a study on the Governance of public Universities observed that the decline in examination performance is partly attributed to the poor quality in educational experience brought about by the increased enrolments. This implies that increased enrollment leads students to leaving off- campus, thereby affecting their examination performance. It could be argued further that when students accommodate themselves off-campus and are challenged with good lighting fixtures, inadequate room spaces and learning facilities, insecurity, long distance, their academic activities such as regular attendance of lectures, library, ding assignments and regular studies would be affected, causing poor examination performance. Sifuna (2012) further points out that the high number of admissions has not been matched with the provision of teaching facilities and resources especially lecture halls and halls of residence. This situation is likely to affect students' performance of academic activities particularly off-campus students.

Housing as a medium for human-environmental interactions, has great influence on human in either ways, negative or positive. Access to healthy housing is vital for healthy living and essential to social equity, efficiency, social behaviour, satisfaction and general welfare of the community (Ghani1\& Suleiman, 2016). It could be said that if students on off-campus accommodation are healthy, enjoy social quality and efficiency as well as demonstrate good social behaviours and satisfaction, they are likely to performwell in academic activities. On the other hand, they may not perform well. In effect, students on off-campus accommodation may show truancy, low academic performance, poor examination performance, lack of interest in learning, poor attendance of library and lectures among others.

\section{Research Methodology}

The descriptive survey design was employed for the study. Leedy and Ormrod (2005) posit that descriptive design involves collecting data in order to test hypothesis or answer research question concerning the current status of a study without modifying or determining cause and effect of the situation under investigation. This study therefore seeks to assess students in off-campus accommodation in the university of education, winneba and the effect on academic activities hence the choice of descriptive survey design.

\section{Study Area and Sample Population}

Though University of Education, Winneba (UEW) has satellite campuses at Kumasi, Mampong and Ajumako, the study focused on UEW, Winneba campus made up of three campuses; North, South and the Central campuses. UEW being a Public University, in Ghana provides policy to manage students' accommodation leading to over 16,831 constituting the population of the study being housed in various types of dwellings outside the three campuses. 
Conceptualizing the students' accommodation Policy of IN-OUT-OUT-OUT, (UEW, 2018)in relation to students engaging in academic activities, the study adopted a multi- stage sampling procedure. Random sampling was used to select 15 hotels from the list of registered hotels with the University. Convenience and snowball sampling were used to select five (5) flatsand (5) compound houses in which students reside. Further, ten (10) students were sampled at random from each hostel, while convenience sampling was used to select ten (10) students from both the flat and compound houses giving a total of Two Hundred and Fifty (250) sample size.

\section{Data Collection}

Using convenience sampling together with the lottery method under the simple random sampling, a total of 250 copies of questionnaire were distributed, and 250 retrieved. The questionnaire was used to collect data from the respondents. A covering letter explaining the rationale of the research and terminologies involved were attached. At each hotel, flat and compound house the researcher took time to explain the various sections of the instruments to respondents to ensure that they understood what they were going to do and also to provide the correct information. Under the guidance and supervision of the researcher, respondents completed all items on the questionnaire which were subsequently collected in two weeks. This gave a $100 \%$ return rate.

\section{Design of Research Questionnaire}

It appears there is limited study on students' off-campus accommodation in UEW and its effects on students' academic activities. Conspicuously, most studies had focused on students' accommodation and its impact on students' academic performance. Other studies also touched on availability of accommodation for students in tertiary institutions which provided solid literature for this study on students in off-campus accommodation and its effects on academic activities in UEW. After carefully streamlining the concept of accommodation in relations to students off-campus accommodation to suit this study, and a critical scrutiny of the questionnaire by pears and supervisors, 20 variables were selected as both factors influencing choice of accommodation and effects of accommodation on students' academic activities.

Basically, the questionnaire was in two parts. Part A sought to seek respondents' view on factors influencing students' choice of accommodation, while Part B sought to seek the respondents' view on effects of off-campus accommodation on students' academic activities.

\section{Data Analysis}

The data collected for the study were sorted, checked and coded. Since the study was a descriptive one, descriptive statistics including the frequency counts of responses, percentages and mean values were used for the analysis of the data. Statistical Product for Service Solution (SPSS version 20.0) was used to get the descriptive statistic for all responses on the questionnaire. Frequency counts and percentage tables were used to present the data collected. The responses of the respondents have been presented in tables.

\section{Findings and Discussions}

\subsection{Factors Considered in the Choice of Accommodation}

This research question seeks to identify the factors considered in the choice of accommodation. The results gathered from the respondents are presented in Table 1.

\begin{tabular}{|c|c|c|c|c|c|}
\hline Factors & $\begin{array}{c}\text { Very } \\
\text { Important } \\
\text { F (\%) }\end{array}$ & $\begin{array}{c}\text { Important } \\
\text { F (\%) }\end{array}$ & $\begin{array}{c}\text { Fairly } \\
\text { Important } \\
\text { F (\%) }\end{array}$ & $\begin{array}{c}\text { Not } \\
\text { Important } \\
\text { F (\%) }\end{array}$ & Mean \\
\hline Security & $181(72.4)$ & $48(19.2)$ & $21(8.4)$ & - & 3.64 \\
\hline Utility & $152(60.8)$ & $58(23.2)$ & $35(14)$ & $5(2.0)$ & 3.43 \\
\hline Sanitation & $153(61.2)$ & $49(19.6)$ & $48(19.2)$ & - & 3.42 \\
\hline $\begin{array}{c}\text { Condition of the } \\
\text { apartment }\end{array}$ & $119(47.6)$ & $82(32.8)$ & $45(18)$ & $4(1.6)$ & 3.26 \\
\hline $\begin{array}{c}\text { Proximity } \\
\text { Number of occupants } \\
\text { in a room }\end{array}$ & $99(39.9)$ & $91(36.4)$ & $40(16)$ & $20(8)$ & 3.07 \\
\hline Neighbourhood & $100(40.0)$ & $71(28.4)$ & $40(15.6)$ & $39(15.6)$ & 2.93 \\
\hline Cost of accommodation & $83(33.2)$ & $85(34.0)$ & $57(22.8)$ & $25(10.0)$ & 2.90 \\
\hline
\end{tabular}

Table 1: Factors Considered in the Choice of Accommodation $n=250$

Source: Field Survey (2018)

The result in Table 1 shows that $72.4 \%$ implied that security was very important in the choice of accommodation, $8.4 \%$ indicated it was important and $19.2 \%$ said fairly important. This finding might be that naturally, safety and security are very fundamental considerations for every person. In addition, majority of the respondents (60.8\%) agreed that utility was a very important factor they took into consideration, $23.2 \%$ said important, $14 \%$ indicated fairly important and $2.0 \%$ said not important. The result points to the fact that $84 \%$ of the respondents considered utility as an important factor in 
the choice of accommodation. This finding agrees with Flanigan, Kenneth and Copeland, (2010) in their research on the housing preferences of undergraduate students which reveal that students preferred housing options that fulfilled their high potentials for privacy and amenities. The argument herein is that when the needed utilities such as bathroom, toilet facilities among other are available and functioning in a house, occupants are likely to enjoy their stay.

On sanitation as a factor of choice, $61.2 \%$ indicated sanitation as a very important factor that led to their choice of accommodation, $19.2 \%$ agreed it was an important factor they considered when choosing an accommodation and $19.6 \%$ considered it as fairly important. The result depicts that most (80.4\%) of the respondents considered sanitation to be important in the choice of accommodation.

On condition of apartment, $47.6 \%$ considered as a very important factor that influenced their choice of accommodation, $32.8 \%$ condition of the said it was important, $18 \%$ said fairly important and $1.6 \%$ indicated it was not important. It could be observed from the results that majority of the respondents (70.8\%) considered the condition of apartment as an important factor in their choice of accommodation. As indicated in the literature, this finding supports the study finding of Krieger and Higgins (2002) who indicated that poor condition of apartment is associated with a wide range of health conditions, including respiratory infections, asthma, lead poisoning injuries, and mental health.

On neighbourhood, 33.2\% indicated neighbourhood as a very important factor, 34\% said it was an important factor they considered $22.8 \%$ said fairly important and $10 \%$ indicated not important. Majority (67.2\%) indicated that they considered neighbourhood as an important factor in their choice of accommodation. This might be because they want a conducive environment so that they could study with very minimal or no disturbance. This is in agreement with de Araujo and Murray (2010)who posit that Location and neighbourhood effect are likely to inform choice of accommodation attributes are perceived as the key factor when it comes to choosing accommodation. In terms of cost of accommodation, $30.8 \%$ indicated that the cost of accommodation was also a very important factor they considered, 31.6\% agreed it was important. However, $25.2 \%$ said it was fairly important. The results point out that majority (62.4\%) agreed that cost of accommodation was important in their choice of accommodation. As pointed out in the literature, this finding relates same to (Khozaei, 2010) on the account that cost of accommodation determines choice, however, it is dependent on rental rates, distance from university facilities, room safety, room size, hostel security, and other facilities in the hostel.

Furthermore, 39.9\% considered proximity as a very important factor they considered when selecting their accommodation, $36.4 \%$ agreed it was important, $16 \%$ said fairly important,while $8.0 \%$ said not important. It can be deduced from the result that majority (76.3\%) of the respondents considered proximity as an important factor in their choice of accommodation. As indicated earlier, proximity as a factor to determine choice of accommodation relates to cost, availability of alternative accommodation among others (Khozaei, 2010).

Again, $40 \%$ considered number of occupants in the room as a very important factor they considered, $28.4 \%$ indicated that it was important, 16\% implied it was fairly important and $15.6 \%$ said it was not an important factor they considered. This analysis reveals that majority of the respondents (80.8\%) considered number of occupations as an important factor to their choice of accommodation. This finding falls through that poor condition of apartment is associated with a wide range of health conditions, including respiratory infections, asthma, lead poisoning injuries, and mental health (Krieger \& Higgins, 2002). In this regard, students are likely to seek privacy, hence choosing off-campus accommodation over on-campus.Subsequently, the mean scores of the factors that affect the respondents' choice of accommodation were also rated to offer support to the discussion. Security had a mean of 3.64 which was the highest, followed by utility with a mean of 3.43. Sanitation followed with a mean of 3.42, condition of apartment with a mean of 3.26. Next was proximity with a mean of 3.08 followed by number of occupants in a room with a mean of 2.93. Neighbourhood had a mean of 2.90 followed by the cost of accommodation with a mean of 2.81. From the above analysis, it is made clear that all the respondents considered all the above-mentioned factors to be important as far as their choice of accommodation is concerned.

\subsection{Effects of Off-Campus Accommodation on the Academic Activities of Students}

The research question sought to find out the effect of off-campus accommodation on the academic activities of offcampus students. The results generated from the respondents are thus presented in Table 2 .

\begin{tabular}{|l|l|l|l|l|l|}
\hline \multicolumn{1}{|c|}{ Effects } & \multicolumn{1}{|c|}{$\begin{array}{c}\text { Always } \\
\text { F (\%) }\end{array}$} & $\begin{array}{c}\text { Sometimes } \\
\mathbf{F ~ ( \% )}\end{array}$ & $\begin{array}{c}\text { Seldom } \\
\mathbf{F ~ ( \% )}\end{array}$ & $\begin{array}{c}\text { Never } \\
\mathbf{F ~ ( \% )}\end{array}$ & Mean \\
\hline Opportunity to do private studies & $14(56.0)$ & $90(36.0)$ & $10(4.0)$ & $10(4.0)$ & 3.44 \\
\hline Hinders access to library & $59(23.6)$ & $120(48.0)$ & $50(20.0)$ & $21(8.4)$ & 2.87 \\
\hline Limit access to internet & $51(20.0)$ & $103(41.2)$ & $69(27.6)$ & $27(10.8)$ & 2.71 \\
\hline $\begin{array}{l}\text { Non - regular participation in } \\
\text { group work }\end{array}$ & $41(16 . .4)$ & $120(48.0)$ & $31(12.4)$ & $58(23.2)$ & 2.58 \\
\hline Lateness to lectures & $28(12.4)$ & $92(36.8)$ & $31(12.4)$ & $96(38.4)$ & 2.23 \\
\hline Poor performance in examination & $10(4.0)$ & $71(28.4)$ & $54(21.6)$ & $115(46.0)$ & 1.90 \\
\hline Poor performance in quizzes & $0(0)$ & $81(32.4)$ & $58(23.2)$ & $111(44.4)$ & 1.88 \\
\hline Late submission of assignments & $4(1.6)$ & $40(16.0)$ & $89(35.6)$ & $117(46.6)$ & 1.72 \\
\hline
\end{tabular}

Table 2: Effect of Off-Campus Accommodation on Students' Academic Activities $n=250$

Source: Field Survey (2018) 
Results from Table 2 reveal that $16.4 \%$ of the respondents indicated that they were always limited to participate in group work, $48 \%$ said sometimes, $12.4 \%$ said seldom and $23.2 \%$ said never. The analysis of the result indicates that majority (64.4\%) of the off-campus residents indicated they were not able to participate in group work. As shown in the literature, the finding agrees with Ndoma (2018) who found lack of hostel accommodation encouraging truancy and consequently poor concentration on academic work.

Again, on access to the library, $23.6 \%$ agreed that off campus accommodation deprived them easy access to the library always, $48 \%$ said sometimes, $20 \%$ said seldom and $8.4 \%$ indicated never. This implies that majority (71.6\%) of the respondents indicated they were deprived easy access to library. This might be due to distance, cost of transportation and others.

In terms of easy access to the internet, $20.4 \%$ signified that off campus accommodation limited their access to the internet always, $41.2 \%$ said sometimes, $27.6 \%$ said seldom and $10.8 \%$ indicated never. This implies that majority (61.4\%) of the respondents had limited access to the internet being off campus residents. This might be because provision and access to internet is a new phenomenon in our part of the world. As such, most private homes in Ghana including those in Winneba, have not yet provided internet access in their homes.

On the contrary, the results indicate that almost all (92.0\%) of the respondents hold the view that off-campus accommodation has no adverse effect on their private studies. This was in response to the statement; I have the opportunity to do private studies. Majority (56.0\%) said always, 36\% said sometimes, 4\% indicated seldom and 4\% also said never. This finding contradicts a related finding of Ndoma (2018) that lack of hostel accommodation encourages truancy and consequently poor concentration on academic work.

Similarly, for lateness to lectures, only (12.4\%) of respondents indicated that they always attended lectures late, $36.8 \%$ said sometimes, $12.4 \%$ said seldom and $38.4 \%$ said never.This finding demonstrates that majority (88.0\%) of respondents do not attend lecture late. The finding seems to suggest that off-campus accommodation does not affect lecture attendance. Again, the finding contradicts Ndoma (2018) on the account that lack of hostel accommodation encourages truancy. In term of poor performance in examinations $4 \%$ agreed that they always perform poorly in examinations, $28.4 \%$ said sometimes $21.6 \%$ said seldom and $46 \%$ also said never.

The result points out that majority $(67.6 \%)$ of the respondents performed well in examination. For lateness in submission of assignments, $1.6 \%$ of the respondents said always, $16 \%$ said sometimes, $35.6 \%$ said seldom and $46.6 \%$ said never The analysis of the result implies most (82.2\%) of the respondents submitted their work on time. Regarding poor performance in quizzes, none $(0 \%)$ of the respondents indicated always, $32.4 \%$ said sometimes, $23.2 \%$ implied seldom and $44.4 \%$ said never. From the results of the analysis majority $(67.6 \%)$ of the respondents indicated that they performed well in their quizzes. The above findings show that students in off-campus accommodation do not perform poorly in examination and quizzes, attend lecture late and do not submit assignments on time. As indicated in the literature, these findings contradictNeema (2003) that students on off-campus accommodation perform lower than their counterparts on campus counterparts. Further, the findings disagree with Sifuna (2012) that the decline in examination performance of students in Boswana is partly attributed to the poor quality in educational experience brought about by the increased enrolments. The argument herein is that increased enrolment of students brought about the off-campus phenomenon.

In support of the findings based on the percentages scores, the mean scores show that off-campus resident students had opportunity to do private studies (3.44), deprived easy access to library. (2.87) and had access to internet (2.71). Similarly, off campus resident students' never submitted assignment late (1.72). More so, the mean score for poor examination in quizzes (1.88) and/or in examinations (1.90).Subsequently, the mean score for sometimes they did not participate in group work regularly was (2.53), they seldom late for lectures (2.23)and seldom had inadequate time for private studies. This result implies that off -campus residents had little or no negative effective on the academic activities of the off-campus students.

\section{Conclusions and Recommendations}

This paper concludes that majority of students on off-campus accommodation in UEW take into account factors such as the security (72.4\%), utility(84.0\%), sanitation (80.4\%), condition of apartment (70.8\%) and proximity (76.3\%). The rest of the factors are number of occupants (80.8\%), neighbourhood (67.3\%) and cost of the apartment $(62.4 \%)$. Subsequently, the study shows that off-campus accommodation has no adverse effect on academic activities on majority of students' in UEW regarding opportunity to do private studies (92.0\%), lateness to lecture (88.0\%), lateness in submission of assignment (82.2\%), poor performance in examination and quizzes (76.8\%) and 67.6\%) respectively. This notwithstanding, off -campus accommodation in UEW adversely affect students'group work (64.4\%), access to library $(71.6 \%)$ and access to internet (61.4\%). The study recommends that providers of hotels, flats and compound homes that accommodate of-campus students should continue to ensure the provision of adequate security, toilets other domestic facilities as well as keeping the sanitation clean to attract more students. However, the facility providers should provide internet at their premises to enable students in off-campus get access to internet, since internet use is inevitable in doing academic work in recent times. Further, students in off-campus are encouraged to form study group particularly those offering the same programmes and courses.

\section{References}

i. Agus, A., \& bin Mohamed Makhbul, Z. K. (2002). An empirical study on academic achievement

ii. of business students in pursuing higher education: an emphasis on the influence of family backgrounds. New Paradigm of Borderless Education: Challenges, Strategies, and Implications for Effective Education through Localization. 
iii. Bromley, R. (2006). On and off campus: Colleges and universities as local stakeholders. Planning, Practice \& Research, 21(1), 1-24.

iv. Brooks, D. J. (2010). What is security: Definition through knowledge categorization.Security Journal, 23(3), 225-239.

v. Cohen, J. E. (2003). Human population: the next half century. Science, 302(5648), 1172-1175.

vi. Dako-Gyeke, M., \&Oduro, R. (2013). Effects of household size on cash transfer utilization for orphans and vulnerable children in rural Ghana. Academic Journal of Interdisciplinary Studies, 2(1), 239.

vii. De Araujo, P., \& Murray, J. (2010). Channels for Improved Performance from Living on Campus. American Journal of Business Education, 3(12), 57-64.

viii. Ghana Education Trust Fund (GETFund). Retrieved on 10/06/2021http://www.getfund.gov.gh

ix. Ghanil, A., \& Suleiman, N. (2016). Theoretical underpinning for understanding student housing. Journal of Environment and Earth Science, 6(1), 24 - 32.

x. Kenyon, E. L. (1997). Seasonal sub-communities: The impact of student households on residential communities. British Journal of Sociology, 286-301.

xi. Khozaei, F., Amole, D., Hassan, A. S., \&Khozaei, Z. (2010). Female graduate students' perception of the relationships between the residence hall and the home. Asian Social Science, 6(10), 68.

xii. Korevaar, D. N. (2004). Proximity, pocketbooks and preferences: a study of University of Calgary off-campus renters. Calgary, Alberta, Canada.

xiii. Krieger, J., \& Higgins, D. L. (2002). Housing and health: time again for public health action. American Journal of Public Health, 92(5), 758-768.

xiv. Leedy, P. S., \&Ormrod, J. E. (2005). Practical research: Planning and design (8 ${ }^{\text {th }}$ ed.). Upper Saddle River, New Jersey: Merrill Prentice Hall.

xv. Maslow, A. H. (1943). A theory of human motivation. Psychological Review, 50(4), 370.

xvi. Mensah, P., Yeboah-Manu, D., Owusu-Darko, K., \&Ablordey, A. (2002). Street foods in Accra, Ghana: how safe are they? Bulletin of the World Health Organization, 80, 546-554.

xvii. Maximillian English dictionary.com retrieved Retrieved on 10/06/2021.

xviii. Modebelu, M. N., \&Chinyere, A. P. (2014). Environmental hazards and hostel accommodation problems: Challenges for university education in Nigeria. US-China Education Review B, Education Theory, 4(6), 407 413.

xix. Najib, N. U., Yusof, N. A., \& Osman, Z. (2011). Measuring satisfaction with student housing facilities. American Journal of Engineering and Applied Sciences, 4(1), 52-60.

xx. Ndoma, J. T. (n.d.). Douglas Chiguvi marketing management lecturer \& PhD Candidate, Department of Entrepreneurship, BA ISAGO University, P. Bag 149, Gaborone, Botswana.

xxi. Neema, I. (2003). Resident student perceptions of on-campus living and study environments at the University of Namibia and their relation to academic performance (PhD Thesis). Worcester Polytechnic Institute.

xxii. Nimako, S. G., \&Bondinuba, F. K. (2013). An empirical evaluation of student accommodation quality in higher education. European Journal of Business and Social Sciences, 1(12), 164-177.

xxiii. Osfield, K. J., \& Terrell, P. S. (2009). Internationalization in higher education and student affairs. The Handbook of Student Affairs Administration :( Sponsored by NASPA, Student Affairs Administrators in Higher Education), 120.

xxiv. Rugg, J., Rhodes, D., \& Jones, A. (2000). The nature and impact of student demand on housing markets. New York, NY: Joseph Rowntree Foundation.

xxv. Sifuna, D. N. (2012). Leadership in Kenyan public universities and the challenges of autonomy and academic freedom: An overview of trends since independence. JHEA/RESA, 10(1), 121-135.

xxvi. University of Education, Winneba (2018). Students accommodation policy. Winneba: University of Education. 